\title{
Financial Development and Economic Growth: Time Series Analysis of Economy of Pakistan
}

\author{
Dr. Muhammad Shoukat Malik \\ Director Institute of Banking and Finance \\ Bahauddin Zakariya University Multan, Pakistan \\ E-mail: shoukatmalik@bzu.edu.pk \\ Raisham Hayee \\ MS (Business Administration) Scholar, Institute of Banking and Finance \\ Bahauddin Zakariya University Multan, Pakistan \\ E-mail: raishamhai@yahoo.com \\ Raima Adeel \\ Visiting lecturer Institute of Management Sciences \\ Bahauddin Zakariya University Multan, Pakistan
}

Received: Oct. 22, 2018 Accepted: Dec. 15, $2018 \quad$ Published: Dec. 21, 2018

doi:10.5296/ifb.v5i2.14091ＵRL: http://dx.doi.org/10.5296/ifb.v5i2.14091

\begin{abstract}
This study aims in understanding the causal relationship between financial development and economic growth. This research used annual data and applied dickey fuller test and granger causality test in order to understand stationary level and causation in variables. The results of this test give support to first hypothesis that financial development causes economic growth. While no evidence was found on the support of our second hypothesis i.e. economic growth is causing financial development.
\end{abstract}

Keywords: Financial development, Economic growth 


\section{Introduction}

The relationship between financial development and economic growth has grabbed the attention of many economists. The financial sector development which is also known as financial system and its relationship with economic growth has been a matter of great concern. This interest has been increased by prominent part of banking sector in economic growth. The finance-led hypothesis got more energy in twentieth century from universal financial institutions like World Bank and the International Monetary Fund and additionally from liberalization scholars like McKinnon (1973) and Shaw (1973). These organizations and researchers state that liberal financial sector assigns more capital to users activates which in turn increase the productivity of physical capital and activate increased amount of financial saving. This will result in the expansion of economic growth. Saint Paul (1992) elucidates that the advancement of financial markets empowers firms to enhance their profitable stocks emerging from varieties in demand and in this manner encourages firms to implement more specialized and productive technology.

Leveine (1997) sorted fundamental elements of financial framework. He characterized them further into five fundamental tasks i.e. to encourage trading, help in the exchange of goods and services, mobilize savings hedging, diversifying of risk allocate resources monitor managers and incorporate corporate control.

Numerous Researches have considered financial development and economic growth as an important area of research. These have studied their relationship by using both time series and cross sectional analysis. According to Beck et al. (2000) financial development has positive relationship with total factor productivity, which causes overall economic growth.

Chen (2006) finds out that financial development in China causes economic growth. He studied the relationship by taking data for the period 1985-1999. His study identified mobilization of savings and the replacement of loans with budget appropriation as a channel of financial sector which add to the economy.

The major objective of this research is

1) What is the relationship in financial development and economic growth?

2) Is there any causal relationship between financial development and economic growth?

The impact of the development of financial sector in achieving economic growth cannot be ignored. Economies are always interested in gaining economic growth. This study is helpful for policy makers to take decisions about the improvement of a better financial system which triggers economic growth. The progress of financial institutions like banks and stock markets helps in mobilizing savings, rising investments and increasing production which causes economic growth.

\section{Literature Review}

Financial development and its relationship with economic growth has been a great a great area to consider by many economists. Many researchers have concluded different relationships between them. Some of scholars have seen a positive relationship, while some 
have also seen negative and neutral relationships between them.

Handa and Khan (2008) examined the economies of thirteen states by taking into view VEC model to unveil the one way connection from economic growth to financial development for Turkey, Malaysia, Sri Lanka, Bangladesh, Brazil and Thailand. Then they also studied for USA, India, Japan, UK Germany, Japan and Argentina and two way relationships were set up and no causation was found for Pakistan.

Osuala et al. (2013) also studied and tried to conclude the presence of a causative linkage in performance of stock market and economic growth in Nigeria. The results showed that one way causal stream from total number of deals ratio as a measure of development of stock market to economic growth.

Bayar et al. (2014) was also curious to explore the relationship between stock market growth and economic growth in case of Turkey. They covered the time period of 1999-2013. They concluded proof of one way connection from market based financial development toward economic growth.

Gokmenoglu et al. (2015) focused on studying the relationship of financial development, economic growth and international trade of Pakistan. They considered the causality between variables by applying Granger causality test. The Data taken in the study was taken from yearly data of nineteen sixty seven to two thousand thirteen including variables as GDP, exports, imports and domestic credit to private sector by banks etc.

By applying the causality results the results demonstrated that economic growth was financial development caused and financial development was economic growth caused in Pakistan. The results of tests of Granger causality demonstrated that an amendment in economic growth and financial development go before an adjustment in import, an amendment in financial development goes before an alteration in economic growth and in the other way. It was found that the greater part of the variables is non-stationary and the examination affirms for a long run connection among financial development, international trade, and also economic growth.

Adeniyi et al. (2012) inspected the causal bond concerning foreign direct investment and economic growth in Sierra Leone, Gambia, Ghana, Cote' d'Ivoire and Nigeria and by taking financial development represented by the time period from 1970-2005. They took trivariate system which applied Granger causality tests in a vector error correction setting.

Their outcomes bolster the perspective that degree with which financial advancement was concerned with the advantages of FDI to enlist on economic growth in Gambia, Sierra Leone and Ghana relying upon the financial indicators of financial sector used. Then again in case of Nigeria no proof was found of any long run or short run causal stream from foreign direct investment to growth by considering financial developing going with.

Adeniyi et al. (2015) reconsider this affiliation in Nigeria. In contrast to existing literature, we endeavored to survey the data substance of non-linearities in the finance-growth nexus for Nigeria. We additionally tried to imaginatively gage the effect of financial changes on the 
Nigerian economy especially as far as economic growth. Utilizing yearly information covering the period 1960-2010, they considered in threshold effects through the financial development (FD) measures as ratio of domestic credit to the private sector as a share of GDP and ratio of liquid liabilities to GDP.

Taken in turn, M3/GDP included the whole liquid liabilities related to financial system by mostly including financial institutions such as the deposit money banks and other non-bank financial institutions and central bank. They concluded that financial development negatively impacted growth but assign reversal resulted on accounting for threshold-type effects. Second, using a composite index of FD led to a similar outcome.

Akinci et al. (2014) concentrated on the connection in the nations which were the member of OECD. The link was explored utilizing unbalanced panel co integration and causality investigation from 1980-2011. Keeping in mind the end goal to quantify financial development different ratios were used as variables of the study to assess financial development i.e. the domestic credits by the banking sectors as a percentage of GDP etc. The consequences of the Pedroni and Kao Co-coordination Examination demonstrated the presence of long run link in financial development and economic growth.

The outcomes of Granger Causality Test showed that there was one way causativeness running from economic growth towards the three of the intermediary variables for financial development while a two way association between expansive measure of cash and economic growth was watched.

Adu et al. (2013) explored the influence of growth in long run on financial development in the economy of Ghana. They noted that growth impact of financial development was sensitive for the decision of intermediary. The credit to the private sector to GDP and total domestic credit were helpful aimed at growth whereas broad money stock to GDP ratio was not growth prompting. The index of principal component analysis confirmed the affectability of the impact to the decision of the choice of proxy. The findings recommended that financial development is great or not for growth relies on upon the indicator used to intermediary for financial development.

Cheng (2012) explored the influence of financial foundations towards economic growth by taking data from Taiwan utilizing information in quarters from the time period of 1973 to 2007 and discovered proof two way causal relations of the financial framework with economic growth in long run.

Zhang et al. (2012) explores the bond of financial development with economic growth by utilizing information of two eighty six Chinese urban areas from 2001-2006.

In order to explore that exogenous segment in financial development completely influenced economic growth a model of growth regression was setup by taking yearly growth rate of GDP as a dependent variable. The data had independent variables which incorporated a variable speaking to financial development and a molding data set controlling of different components. 
They utilized, total household savings deposited in financial system to GDP, deposits in financial system to GDP, proportion of total loans in financial to GDP as the indicators of financial development and economic growth in the economy of China.

Their outcomes of both conventional cross sectional regressions \& first-differenced framework and GMM estimators of element board information recommend that maximum customary pointers of financial development were emphatically connected by economic growth. Their outcome ran opposite to current determination that state ruled banking segment that in China delays economic growth due to of the misleading nature of government.

This relationship is studied by different scholars in different countries but they have considered a very small data so it has less reliability and They have not studied the causative link of Financial Development and Economic Growth at such a large scale. The above literature concluded that there exists a link in financial development and economic growth and its relationship can be positive, negative and neutral. The previous literature also suggested that relationship concerning financial development and economic growth depends upon the variables chosen, sample of country and country conditions to study the relationship. The previous researches also concluded that some causal link is present in financial development and economic growth. This causal relationship also depends upon country to country.

\section{Research Methodology}

Based on above literature and research gap following hypothesis are concluded

\section{H1 Financial development causes Economic growth}

H1-a Domestic credit to Private sector by banks as \% of GDP Ratio Cause GDP

H1-b Bank Deposits as \% of GDP Ratio Cause GDP

H1-c Stock Market Capitalization to GDP Ratio Cause GDP

H1-d Private Sector Credit by Deposit Money Banks and Other Financial Institutions to GDP Ratio Cause GDP

\section{H2 Economic growth causes financial development}

H2- a GDP Cause Domestic credit to Private sector by banks\% of GDP Ratio

H2-b GDP Cause Bank Deposits \% of GDP Ratio

H2-c GDP Cause Stock Market Capitalization to GDP Ratio

H2-d GDP Cause Private Sector Credit by Deposit money banks and Other Financial Institutions to GDP Ratio

\subsection{Data}

This research has used the sample consisting of yearly data of fifty years from 1961 to 2010 . This research has used four variables for measuring financial development and one variable 


\section{Macrothink}

for measuring economic growth. This research has considered to study the data of Pakistan. The financial development variables are Domestic credit to Private sector by banks as percent of GDP Ratio(DCPB), Bank Deposits as percent of GDP Ratio(BD), Stock Market Capitalization to GDP Ratio(STCAP) and Private Sector Credit by Deposit Money Banks and Other Financial Institutions to GDP Ratio(PCBF). The economic growth is measured by GDP. The data is collected from World Bank economic indicators.

This study applied dickey fuller test to study stationary level of variables. Augmented Dickey-Fuller test (ADF) is an augmented form of Dickey Fuller Test. It is a unit root test for time series sample which is used to check the stationary level of variables.

$Y_{t}=\rho \mathrm{Yt}_{-1}+\mathrm{e}_{\mathrm{t}}$

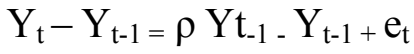

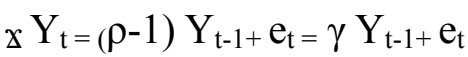

This test is also used by other scholars in their researches i.e. Carp (2012) and Simwaka et al. (2012) also used ADF test to check the stationary level in variables.

In order to check the causation between variables granger causality test is applied.If we want to check the null hypothesis of a stationary time series $\mathrm{x}$ and $\mathrm{y}$, then to check the hypothesis that $\mathrm{x}$ does not cause $\mathrm{y}$ lagged values will be included.

$\mathrm{DCPB}_{\mathrm{t}}=\sum_{j=1}^{2} \mathrm{a}_{\mathrm{j}} \mathrm{DCPB}_{\mathrm{t}-\mathrm{j}}+\sum_{j=1}^{2} \mathrm{~b}_{\mathrm{j}} \mathrm{GDP}_{\mathrm{t}-\mathrm{j}}+€_{\mathrm{t}}$

$\mathrm{GDP}_{\mathrm{t}}=\sum_{j=1}^{2} \mathrm{c}_{\mathrm{j}} \mathrm{GDP}_{\mathrm{t}-\mathrm{j}}+\sum_{j=1}^{2} \mathrm{~d}_{\mathrm{j}} \mathrm{DCPB}_{\mathrm{t}-\mathrm{j}}+r_{\mathrm{t}}$

$\mathrm{BD}_{\mathrm{t}}=\sum_{j=1}^{2} \mathrm{a}_{\mathrm{j}} \mathrm{BD}_{\mathrm{t}-\mathrm{j}}+\sum_{j=1}^{2} \mathrm{~b}_{\mathrm{j}} \mathrm{GDP}_{\mathrm{t}-\mathrm{j}}+\epsilon_{\mathrm{t}}$

$\mathrm{GDP}_{\mathrm{t}}=\sum_{j=1}^{2} \mathrm{c}_{\mathrm{j}} \mathrm{GDP}_{\mathrm{t}-\mathrm{j}}+\sum_{j=1}^{2} \mathrm{~d}_{\mathrm{j}} \mathrm{BD}_{\mathrm{t}-\mathrm{j}}+\mathrm{r}_{\mathrm{t}}$

$\operatorname{STCAP}_{\mathrm{t}}=\sum_{j=1}^{2} \mathrm{a}_{\mathrm{j}} \operatorname{STCAP}_{\mathrm{t}-\mathrm{j}}+\sum_{j=1}^{2} \mathrm{~b}_{\mathrm{j}} \operatorname{GDP}_{\mathrm{t}-\mathrm{j}}+\epsilon_{\mathrm{t}}$

$\operatorname{GDP}_{\mathrm{t}}=\sum_{j=1}^{2} \mathrm{c}_{\mathrm{j}} \operatorname{GDP}_{\mathrm{t}-\mathrm{j}}+\sum_{j=1}^{2} \mathrm{~d}_{\mathrm{j}} \operatorname{STCAP}_{\mathrm{t}-\mathrm{j}}+\eta_{\mathrm{t}}$

$\operatorname{PCBF}_{\mathrm{t}}=\sum_{j=1}^{2} \mathrm{a}_{\mathrm{j}} \mathrm{PCBF}_{\mathrm{t}-\mathrm{j}}+\sum_{j=1}^{2} \mathrm{~b}_{\mathrm{j}} \mathrm{GDP}_{\mathrm{t}-\mathrm{j}}+€_{\mathrm{t}}$

$\mathrm{GDP}_{\mathrm{t}}=\sum_{j=1}^{2} \mathrm{c}_{\mathrm{j}} \mathrm{GDP}_{\mathrm{t}-\mathrm{j}}+\sum_{j=1}^{2} \mathrm{~d}_{\mathrm{j}} \mathrm{PCBF}_{\mathrm{t}-\mathrm{j}}+\mathrm{n}_{\mathrm{t}}$

Whereas a,b,c,d are constant terms and $\mathrm{j}_{1} \rightarrow 2$

Shahbaz et al. (2008), Marques et al. (2013) and Kar and Pentecost (2000) also applied 


\section{Mll Macrothink}

granger causality test in their researches to study the causal relationship between variables.

\section{Results}

\subsection{Results of ADF Test}

As mentioned in the earlier chapter dickey fuller test is used to check that our data is stationary or not. All of the variables are checked at level to test that these are stationary or not. At level data is checked without taking any differences. The results of variables at level are given below.

Table 1. Results of ADF test at level

\begin{tabular}{lllllll}
\hline Variables & P Value & T Statistics & $\begin{array}{l}\mathbf{1 \% c r i t i c a l} \\
\text { value }\end{array}$ & $\begin{array}{l}\mathbf{5 \% c r i t i c a l} \\
\text { value }\end{array}$ & $\begin{array}{l}\mathbf{1 0 \% c r i t i c a l} \\
\text { value }\end{array}$ & Decision \\
\hline PCBF & 0.2851 & -2.003 & -3.587 & -2.933 & -2.601 & Non stationary \\
STCAP & 0.3368 & 1.89 & -3.587 & -2.933 & -2.601 & Non stationary \\
BD & 0.0947 & -2.592 & -3.587 & -2.933 & -2.601 & Non stationary \\
DCPB & $0.0009^{* *}$ & -4.127 & -3.587 & -2.933 & -2.601 & Stationary \\
GDP & $0.0000^{* *}$ & -5.8 & -3.587 & -2.933 & -2.601 & Stationary \\
\hline
\end{tabular}

The results of ADF shows that at level only two variables i.e. Domestic credit to Private sector by banks as percent of GDP Ratio and GDP is stationary at 5\% level of significance. Others variables are non -stationary. Now in order to make variables stationary their results are checked by taking first difference.

The outputs of variables by taking first difference are demonstrated below:

\subsubsection{Results of ADF at First Difference}

Table 2. Results of ADF test at first difference

\begin{tabular}{lllllll}
\hline Variable & P Value & Test Statistics & $\begin{array}{l}\mathbf{1 \%} \text { critical } \\
\text { value }\end{array}$ & $\begin{array}{l}\mathbf{5 \%} \text { critical } \\
\text { value }\end{array}$ & $\begin{array}{l}\mathbf{1 0 \%} \text { critical } \\
\text { value }\end{array}$ & Decision \\
\hline PCBF & $0.002^{* *}$ & -3.875 & -3.594 & -2.936 & -2.602 & Stationary \\
STCAP & $0.0513^{* *}$ & -2.852 & -3.594 & -2.936 & -2.602 & Stationary \\
BD & $0.0242^{* *}$ & -3.133 & -3.594 & -2.936 & -2.602 & Stationary \\
DCPB & $0.0007^{* *}$ & -4.178 & -3.594 & -2.936 & -2.602 & Stationary \\
GDP & $0.0028^{* *}$ & -3.81 & -3.594 & -2.936 & -2.602 & Stationary \\
\hline
\end{tabular}

At first difference all variables are stationary as their $\mathrm{p}$ value is less than 0.05 except Stock Market Capitalization to GDP Ratio which is also near to stationary at $5 \%$ level of significance. 


\subsection{Results of Granger Causality}

\subsubsection{Purpose}

The basic purpose of this test is to check causality between variables. The test is applied in this study to check the causality relationship concerning financial development and economic growth. This test will check that whether financial development is causing economic growth or economic growth is causing financial development.

\subsubsection{Output}

The outputs of this test are shown in table below. These results are taken at lag 2. These outputs show that $\mathrm{H} 1$ is accepted and $\mathrm{H} 2$ is rejected. The detail discussion of hypothesis and results are here.

Table 3. Results of Granger Causality

\begin{tabular}{llll}
\hline $\begin{array}{l}\text { Pairwise Granger Causality Tests } \\
\text { Date: } 03 / 28 / 16 \quad \text { Time: } 12: 46\end{array}$ & & & \\
Sample: 19612010 & & & \\
Lags: 2 & Obs & F-Statistic & Prob. \\
\hline Null Hypothesis: & 48 & 3.86927 & 0.0285 \\
DCPB does not Granger Cause GDP & & 1.38585 & 0.2611 \\
GDP does not Granger Cause DCPB & 48 & 2.36207 & 0.1063 \\
BD does not Granger Cause GDP & & 0.70479 & 0.4998 \\
GDP does not Granger Cause BD & 48 & 4.14497 & 0.0226 \\
STCAP does not Granger Cause GDP & & 0.88512 & 0.4200 \\
GDP does not Granger Cause STCAP & 48 & 2.58578 & 0.0870 \\
PCBF does not Granger Cause GDP & & 1.55452 & 0.2229 \\
GDP does not Granger Cause PCBF & & & \\
\hline
\end{tabular}

The results of granger causality are tested by taking two lags of data. The lags are selected according to model selection criteria. At lag two maximum variables are related. The $\mathrm{p}$ value of $\mathrm{H} 01-\mathrm{a}$ is 0.0285 . The $\mathrm{p}$ value is less than 0.05 so $\mathrm{H} 1-\mathrm{a}$ is accepted. The $\mathrm{p}$ value of H01-b is 0.1063 . The $\mathrm{p}$ value is greater than 0.05 so $\mathrm{H} 1-\mathrm{b}$ is rejected. The $\mathrm{p}$ value of $\mathrm{H} 01-\mathrm{c}$ is 0.0226 . The $p$ value is less than 0.05 so H1-c is accepted. The $p$ value of H01-d is 0.0870 . H01-d is accepted. Overall $\mathrm{H} 1$ is accepted. This results shows that financial development causes economic growth (Gokmenoglu et al., 2015; Simwaka et al., 2012).

The results of Granger Causality for $\mathrm{H} 2$ shows that all the hypothesis are rejected at $1 \%, 5 \%$ and $10 \%$ level of significance so H2 Economic Growth cause Financial Development is rejected. The results of this hypothesis are in support with the studies of Christopoulos and Tsionas (2004), Yang and Yi (2008). 


\section{Conclusion}

The present paper contributed in studying the causative relationship of financial development and economic growth by considering the economy of Pakistan. Several studies have taken panel data while other used time series data in their researches. The data taken to analyze the relationship is time series data and it covers the sample from 1961 to 2010. First of all Augmented Dickey Fuller Test was applied to check that whether variables are stationary or not. The results disclosed that all the variables were stationary at first difference. After checking stationary level of variables Granger Causality Test was applied. As the variables were stationary at first difference the results of granger causality were also significant by taking second lag. The results of this test give support to first hypothesis that financial development is causing economic growth. While no evidence was found on the support of our second hypothesis i.e. economic growth is causing financial development.

\section{References}

Adeniyi, O., Omisakin, O., Egwaikhide, F. O., \& Oyinlola, A. (2012). Foreign direct investment, economic growth and financial sector development in small open developing economies. Economic Analysis and Policy, 42(1), 105-127. https://doi.org/10.1016/S0313-5926(12)50008-1

Adeniyi, O., Oyinlola, A., Omisakin, O., \& Egwaikhide, F. (2015). Financial development and economic growth in Nigeria: Evidence from threshold modelling. Economic Analysis and Policy, 47, 11-21. https://doi.org/10.1016/j.eap.2015.06.003

Adu, G., Marbuah, G., \& Mensah, J. (2013). Financial development and economic growth in Ghana: Does the measure of financial development matter? Review of Development Finance, 3, 192-203. https://doi.org/10.1016/j.rdf.2013.11.001

Akinci, G. Y., Akinci, M., \& Yilmaz, Ö. (2014). Financial Development-Economic Growth Nexus: A Panel Data Analysis Upon Oecd Countries. Hitotsubashi Journal of Economics, $33-50$.

Bayar, Y., Kaya, A., \& Yildirim, M. (2014). Effects of stock market development on economic growth: Evidence from Turkey. International Journal of Financial Research, 5(1), 93. https://doi.org/10.5430/ijfr.v5n1p93

Beck, T., Levine, R., \& Loayza, N. (2000). Finance and the Sources of Growth. Journal of Financial Economics, 58(1), 261-300. https://doi.org/10.1016/S0304-405X(00)00072-6

Carp, L. (2012). Can stock market development boost economic growth? Empirical evidence from emerging markets in Central and Eastern Europe. Procedia Economics and Finance, 3, 438-444. https://doi.org/10.1016/S2212-5671(12)00177-3

Chen, H. (2006). Development of financial intermediation and economic growth: The Chinese experience. China Economic Review, 17(4), 347-362. https://doi.org/10.1016/j.chieco.2006.01.001

Cheng, S. Y. (2012). Substitution or complementary effects between banking and stock 
markets: Evidence from financial openness in Taiwan. Journal of International Financial Markets, Institutions and Money, 22(3), 508-520. https://doi.org/10.1016/j.intfin.2012.01.007

Christopoulos, D., \& Tsionas, E. (2004). Financial development and economic growth: evidence from panel unit root and cointegration tests. Journal of Development Economics, 73, 55-74. https://doi.org/10.1016/j.jdeveco.2003.03.002

Gokmenoglu, K., Amin, M., \& Taspinar, N. (2015). The Relationship among International Trade, Financial Development and Economic Growth: The Case of Pakistan. Elsevier Procedia Economics and Finance, 5, 489-496. https://doi.org/10.1016/S2212-5671(15)00761-3

Handa, J., \& Khan, S. R. (2008). Financial development and economic growth: a symbiotic relationship. Applied Financial Economics, 18(13), 1033-1049. https://doi.org/10.1080/09603100701477275

Kar, M., \& Pentecost, E. J. (2000). Financial development and economic growth in Turkey: further evidence on the causality issue. Economic Research Paper, 27.

Levine, R. (1997). Financial development and economic growth: views and agenda. Journal of Economic Literature, 35(2), 688-726.

Marques, L. M., Fuinhas, J. A., \& Marques, A. C. (2013). Does the stock market cause economic growth? Portuguese evidence of economic regime change. Economic Modelling, 32, 316-324. https://doi.org/10.1016/j.econmod.2013.02.015

McKinnon, R. I. (1973). Money and capital in economic development. Brookings Institution Press.

Osuala, A. E., Okereke, J. E., \& Nwansi, G. U. (2013). Does stock market development promote economic growth in emerging markets? A causality evidence from Nigeria. World Review of Business Research, 3(4), 1-13.

Saint-Paul, G. (1992). Technological choice, financial markets and economic development. European Economic Review, 36(4), 763-781. https://doi.org/10.1016/0014-2921(92)90056-3

Shahbaz, M., Ahmed, N., \& Ali, L. (2008). Stock market development and economic growth: ARDL causality in Pakistan. International Research Journal of Finance and Economics, 14(1), 182-195.

Shaw, E. S. (1973). Financial deepening in economic development.

Simwaka, K., Munthali, T., Chiumia, A., \& Kabango, G. (2012). Financial development and economic growth in Malawi: An Empirical Analysis. Banks and Bank Systems, 7(3), 85-96.

Yang, Y. Y., \& Yi, M. H. (2008). Does financial development cause economic growth? Implication for policy in Korea. Journal of Policy Modeling, 30(5), 827-840. https://doi.org/10.1016/j.jpolmod.2007.09.006

Zhang, J., Wang, L., \& Wang, S. (2012). Financial development and economic growth: 


\section{Macrothink}

Recent evidence from China. Journal of Comparative Economics, 40, 393-412. https://doi.org/10.1016/j.jce.2012.01.001

\section{Copyrights}

Copyright for this article is retained by the author(s), with first publication rights granted to the journal.

This is an open-access article distributed under the terms and conditions of the Creative Commons Attribution license (http://creativecommons.org/licenses/by/4.0/). 